\title{
Analysis of Allergen Components and Identification of Bioactivity of HSP70 in Pollen of Populus Deltoides
}

\section{Wei Guo}

Anhui Normal University

\section{Xiaodong Zhan}

Wannan Medical College

Feng Jiang

Wannan Medical College

Yilong Xi ( $\nabla$ ylxi1965@126.com )

Anhui Normal University

\section{Research}

Keywords: Populus deltoides pollen, Proteosome, Hsp 70, Allergen, Allergic disease

Posted Date: May 26th, 2021

DOI: https://doi.org/10.21203/rs.3.rs-541522/v1

License: (c) (i) This work is licensed under a Creative Commons Attribution 4.0 International License. Read Full License 


\section{Abstract}

Background: Allergies caused by pollen from Populus deltoides are common, but the allergic components are still unclear.

Methods: The total proteins in pollen of $P$. deltoides were analyzed by proteomics, and the potential allergens were identified via the WHO/IUIS database and the allergenOnline database retrieval. The target protein was screened by bioinformatics and expressed in Escherichia coli. The biological activity of the expressed product was verified by animal experiments.

Results: 3929 total proteins in pollen of $P$. deltoides were identified, and 49 potential allergens belonging to 10 protein families were recognized by database retrieval. B9N9W6 protein of Hsp 70 family was screened by bioinformatics analysis and expressed successfully. ELISA showed that B9N9W6 can stimulate the immune system to produce specific IgE and promote the generation of IL-4. Flow cytometry showed that B9N9W6 can significantly stimulate the proliferation of $C D 4^{+} T$ cells and promote the polarization of Th2 cells. The pathological sections of mice lung tissues indicated that alveolar destruction was more severe in the B9N9W6 group than that of extract group, and there were more inflammatory cells infiltration, mucus exudation and bleeding.

Conclusion: B9N9W6 is an important antigenic substance in the pollen of $P$. deltoides. Due to the conserved structure of Hsp 70 family, more attention should be paid to the possibility of sensitization when HSP 70 from any pathogenic species is administered.

\section{Background}

Allergic asthma is a chronic airway inflammation disease, which characterized by chest tightness, shortness of breath, and coughing after exposure to allergens [1]. The incidence of allergic asthma has been increasing in recent years [2]. At least 300 million people suffer from allergic asthma worldwide [3], which is highest among children $[4,5]$. The main pathogenesis of allergic asthma is the production of specific IgE antibody, chronic airway inflammation and airway hyperresponsiveness during the immune system response to allergens in the environment, accompanied by the imbalance of Th1/Th2 cells and other comprehensive factors [6-8].

Pollen from plants is an important source of air-borne allergens, which seriously affects the quality of life for people who is susceptible to allergies [9]. During the period of flower opening, pollen grains are released into the air to form biological aerosols; thus, individuals are inevitably exposed to pollen. Populus deltoides is widely cultivated in China due to its urban greening, windbreak, and sand-fixing berm. In May of each year, mature pollen of $P$. deltoides is densely suspended in the air, which causes a mass of pollen to frequently contact people's eyes, nostrils, mouth and skin, leading to tears, sneezing, itching and other symptoms. Our recent studies demonstrated that mature pollen of $P$. deltoides extract contains antigenic substances with strong sensitization. However, allergic components in $P$. deltoides pollen remain largely unclear. 
The identification and purification of pollen allergens is of great significance for pollen allergy disease, especially in diagnosis and allergen immunotherapy (AIT). In recent years, proteomic techniques have become powerful tools for comprehensive allergen analysis, such as Par h 1 in Parthenium hysterophorus, and Art an 7 in Artemisia vulgaris were identified by this method [10, 11]. In China, proteomics was used to analyze and compare the possible allergens in mutants of $P$. deltoides $[12,13]$. Wang et al. have analyzed the possible allergen components in Populus Tomentosa by proteomics [14]. However, a systematic experimental basis is lacking for the identification of allergens in $P$. deltoides pollen.

HSP (Heat Shock Protein) 70 domain protein has a subtle relationship with allergic diseases. Previous studies have found that Hsp70 is an important mediator to mediate allergic reactions and is capable of binding IgE antibodies in allergic patients [15]. The levels of Hsp70 are significantly elevated in patients with allergic rhinitis [16]. Interestingly, Hsp 70 is widely present in plant pollen as a pan-allergen, which could be responsible for a part of the allergenic cross-reactivity between proteins from different pollens and plant food [17]. However, the biological function of Hsp 70 remains largely unknown.

To screen and verify P. deltoides pollen allergens, we analyzed the total protein of pollen through proteomics. Then, the sequences of identified protein were compared with the confirmed allergen via relevant allergen database to identify the allergen components in pollen. After that, Hsp 70 was expressed in prokaryotic expression system and explored its biological function by animal models. As far as we know, this is the first report of comprehensive allergenic proteins and Hsp 70 biological function in pollen of $P$. deltoides.

\section{Materials And Methods}

\section{P. deltoides pollen sample}

The pollen samples of $P$. deltoides used in this study were collected at the Yangtze River embankment (Wuhu, China) from Apr 20 to May 20, 2018, and stored in a refrigerator at $-80^{\circ} \mathrm{C}$.

\section{Experimental animal}

A total of 30 SPF female BALB/c mice (6-weeks) were purchased from Shanghai Slack Laboratory Animal Co., Ltd. (License number: 20170005030182). The animals were kept under Specific Pathogen Free (SPF) laboratory conditions in the Hangzhou Hibio Technology Co. Ltd, with the room temperature at $22-26^{\circ} \mathrm{C}$, light and darkness for 12 hours, respectively. Animals were free to eat and drink.

\section{Protein extraction}

Protein preparation for proteomics was as follows: The pollen samples were treated with trichloroacetic acid with a final concentration of $20 \%$ at $4^{\circ} \mathrm{C}$ for $2 \mathrm{~h}$, centrifuged at $12000 \mathrm{~g}$ at $4^{\circ} \mathrm{C}$ for $3 \mathrm{~min}$, and the supernatant was discarded. The protein precipitate was washed three times with pre-cooled acetone and reconstituted with $8 \mathrm{M}$ urea. Then, the proteins were analyzed by $12 \%$ SDS-PAGE. Protein preparation for 
animal experiments was as follows: Dried pollen was extracted with PBS (solid-liquid ratio of $1 \mathrm{~g}: 20 \mathrm{~mL}$ ) at room temperature (RT) for 24 hours. The extracted materials were precipitated at RT for 8 hours. The crude extracts were filtered through $20 \mu \mathrm{m}$ filter paper. Then, the extracts were sterilized through a 0.22 $\mu \mathrm{m}$ strainer (Millex GP) and stored at $4^{\circ} \mathrm{C}$. Finally, the protein concentration was measured by the BCA kit (Sangon, C503071-0250).

\section{Proteomics analysis of $\mathrm{P}$. deltoides pollen}

Proteomics analysis was performed with reference to relevant study methods [18]. The main process was as follows: total protein was digested with trypsin, and the tryptic peptides were fractionated into fractions by high pH reverse-phase HPLC using Agilent 300Extend C18 column. The tryptic peptides were analyzed via LC-MS/MS, and. We map and annotate the obtained MS/MS data using Maxquant software (v1.5.2.8). Subsequently, all the annotated peptide data were classified by R software for gene ontology classification and KEGG signaling pathway enrichment. The thresholds for the identification of total proteins and potential allergens in P. deltoides pollen were determined by relevant literature [19].

\section{Screening of potential allergens in the Hsp70 protein family}

The potential allergens of the Hsp70 protein family were screened by following steps. First, we performed T/B cell epitopes prediction for potential allergens of the Hsp70 protein family using the Immune Epitope Database and Analysis Resource (IEDB) ( http://www.iedb.org/ ). Then, Antigenicity of the HSP70 were predicted through Vaxijen v2.0 (http://www.ddgpharmfac.net/vaxijen/VaxiJen/VaxiJen.html) (Threshold 0.4). The formula, molecular weight (MW), stability and isoelectric point (PI) for B9N9W6 were predicted via ExPASy (http://web.expasy.org/protparam/), and its solubility was analyzed by ProtScale (http://web.Expasy.org/protscale/). Thirdly, we performed sequence alignment with HSP70s through the known allergens reported in the WHO/IUIS database and AllergenOnline database, respectively. Finally, we used Swiss-model for homology modeling to screen out Hsp70 with the highest surface complementarity with IgE antibody.

\section{Prokaryotic expression and purification of Hsp70}

Availability of adequate amounts of the pure allergens is essential to further understand their molecular structures, which is a pre-requisite for the development of more efficacious allergen immunotherapy. The amino acid sequences and coding genes of Hsp 70 were retrieved from Uniprot database. The gene of Hsp 70 was synthesized and cloned into prokaryotic expression vector pET-28a (+). The expression of His-tagged recombinant Hsp 70 in transformant $E$. coliBL21 was induced by IPTG (final concentration $=1$ $\mathrm{mmol} / \mathrm{L}$ ), and the expression products were analyzed by SDS-PAGE. Then, the bacteria were collected and disrupted by sonication. Hsp 70 was purified by Ni-NTA protein purification kit (Sangon, C600320-0001), and protein concentration was measured by the protein concentration assay kit (Sangon, C503071-0250).

\section{Preparation of asthmatic model}

All BALB/c mice were randomly divided into 3 groups (10 mice in each group): PBS group, pollen extract group, and Hsp 70 group. Mice in extract group and Hsp 70 group were injected intraperitoneally with 10 
$\mu \mathrm{g}$ pollen extract or Hsp 70 [dissolved in 4\% (W/V) $\mathrm{Al}(\mathrm{OH})_{3}$ in PBS, endotoxin-free] on 0, 7, and 14 days, respectively, to sensitize. From the $21 \mathrm{st}$ day, $0.5 \mu \mathrm{g} / \mathrm{ml}$ pollen extract or Hsp 70 suspension was sprayed for excitation for $30 \mathrm{~min} /$ time for one week. The PBS group was replaced with PBS containing 4\% (W/V) $\mathrm{Al}(\mathrm{OH})_{3}$. Mice in each group were injected intraperitoneally with $0.8 \mathrm{mg} \mathrm{BrdU}$ (dissolved in PBS) before the last challenge. After 24 hours, blood was taken from the eye socket, left at $4^{\circ} \mathrm{C}$ for 2 hours, and centrifuged at $4000 \mathrm{~g}$ for 5 minutes. The collected serum was stored at $-80^{\circ} \mathrm{C}$.

\section{Enzyme-linked immunosorbent assay (ELISA)}

The levels of total IgE antibody and IL-4 in serum were measured by ELISA kits from Songon, Inc. and Jianglaibio (Shanghai, China) (Sangon, D721094 \Jianglaibio, JL20266) according to the manufacturer's protocol.

\section{Flow cytometry}

The spleens of mice in each experimental group were aseptically collected, and splenic cell suspension was prepared. The proliferation of $\mathrm{CD}^{+} \mathrm{T}$ cells and the ratio of Th1/Th2 in spleen cell suspension were detected according to the reported method [20]. In brief, the Th1/Th2 ratio in the splenic cell suspension was detected by the Th1/Th2 flow cytometry kit (Lianke Biotech, No. 70-KTH201) according to the kit's instructions. Cell suspension was incubated for one hour at RT in the dark after adding Anti-mouse CD4FITC antibody (Invitrogen, No. 11-0042-85) and Brdu-PE antibody (Invitrogen, No. 12-5071-41), respectively, and then determined by flow cytometry.

\section{Histological analysis}

After the mice lung tissues were embedded in paraffin, sectioned ( $5 \mu \mathrm{m}$ thick), and hydrated with a series of alcohol, stained with hematoxylin and eosin (H\&E), and then the changes in lung tissue structure were observed with a Nikon Ni-E microscope. Images were captured with a Nikon DS-Ri2 camera.

\section{Statistical Analysis}

Data are expressed as mean \pm standard deviation (SD). Data analysis was performed with SPSS16.0 statistical software package. One-way analysis of variance (ANOVA) was used for the comparison of multiple sample means, and the least significant difference (LSD) method and Tamhane's T2 method were used for the comparison between the two samples. The statistical test level $a=0.05$.

\section{Results}

\section{Definition of P. deltoides pollen proteome}

In the present study, we have used workflow (Fig. 1) to classify its allergen families and to characterize new $P$. deltoides pollen allergen candidates. Mass spectrometry data of the $P$. deltoides pollen proteome showed that the protein mass was mainly concentrated within $150 \mathrm{kD}$, and the protein sequence coverage was mainly below $40 \%$ (Fig. 2A). The quantitative analysis of peptide length showed that peptides were 
mainly distributed in the length of 7-27 amino acid residues, and the number of peptides with length 717AA was relatively concentrated (Fig. 2B).

Analysis by LCMS/MS showed that a total of 3, 929 different proteins were identified. Gene ontology revealed that in terms of biological processes, these peptides were mainly involved in the metabolic process $(32.49 \%)$, cellular process $(27.26 \%)$ and single-organism process (19.21\%) (Fig. 3A). From the perspective of cell components, it mainly involves cell (38.83\%), organelle (23.74\%), membrane (16.63\%) and macromolecular complex (16.09\%) (Fig. 3B). As for molecular functions, $43.35 \%$ of peptides were involved in catalytic activity, and $43.32 \%$ of peptides were related to binding (Fig. 3C). The subcellular localization results showed that $37.47 \%$ of the peptides were located in the chloroplast, $28.86 \%$ of the peptides were located in the cytoplasm, and $14.07 \%$ of the peptides were located in the nucleus (Fig. 3D).

\section{Enrichment analysis of the KEGG signaling pathway and domains contained peptides}

Enrichment analysis on the 3929 identified peptides showed that the top 5 signal pathways that were significantly enriched were ribosome, carbon metabolism, biosynthesis of amino acids, citrate cycle, and proteasome (Fig. 4A). The domain enrichment results showed that the top three domains were Aldolasetype TIM barrel, Heat shock protein 70kD C-terminal domain and Translation protein beta-barrel domain (Fig. 4B).

\section{Allergenic protein families and candidate allergenic proteins}

Sequence alignment between the WHO/IUIS database and the allergenOnline database identified 49 potential allergens that belonged to 10 protein families (Table 1). 
Table 1

The information of predicted allergenic proteins in the pollen of P. deltoides

\begin{tabular}{|lllll|}
\hline $\begin{array}{l}\text { Allergenic protein } \\
\text { family }\end{array}$ & $\begin{array}{l}\text { Protein } \\
\text { accession }\end{array}$ & Identity (\%) & Protein description & Sum \\
\hline $\begin{array}{l}\text { pathogenesis- } \\
\text { related proteins }\end{array}$ & A9PHF7 & $\begin{array}{l}\text { Hev B 6 } \\
(95.2 \%)\end{array}$ & $\begin{array}{l}\text { Class 4 pathogenesis-related } \\
\text { family protein }\end{array}$ & 1 \\
\hline Profilins & A9P8N4 & $\begin{array}{l}\text { Hev b 8 } \\
(94.7 \%)\end{array}$ & Profilin & 1 \\
\hline Peroxidases & B9GYJ9 & $\begin{array}{l}\text { Che a 3 } \\
(61.8 \%)\end{array}$ & Peroxidase & 1 \\
\hline $\begin{array}{l}\text { Seed storage } \\
\text { proteins }\end{array}$ & A0A2K1ZNE2 & $\begin{array}{l}\text { Gly } \mathrm{m} \mathrm{Bd} \\
(62.2 \%)\end{array}$ & Vicilin-like seed storage protein & 3 \\
& B9H8M2 & $\begin{array}{l}\text { Pis } 2 \\
(78.9 \%)\end{array}$ & 11S globulin seed storage protein & \\
& B9HNV4 & $\begin{array}{l}\text { Ana o } 2 \\
(75.3 \%)\end{array}$ & & \\
\hline
\end{tabular}

Note: Only homologous allergen with the highest identity has been displayed.

Identity, homologous allergen in the AllergenOnline database. Sum, total potential pollen allergens identified in the family. 


\begin{tabular}{|c|c|c|c|c|}
\hline $\begin{array}{l}\text { Allergenic protein } \\
\text { family }\end{array}$ & $\begin{array}{l}\text { Protein } \\
\text { accession }\end{array}$ & Identity (\%) & Protein description & Sum \\
\hline \multirow[t]{21}{*}{ Proteases } & \multirow{2}{*}{$\begin{array}{l}\text { A0A2K1XV49 } \\
\text { A0A2K1ZSB7 }\end{array}$} & $\begin{array}{l}\text { Der p } 15 \\
(57.3 \%)\end{array}$ & $\begin{array}{l}\text { Protease Do-like } 2 \text { Subtilisin-like } \\
\text { protease }\end{array}$ & \multirow[t]{21}{*}{16} \\
\hline & & Pen c 1 & \multirow{5}{*}{$\begin{array}{l}\text { Cysteine protease } \\
\text { ATP-dependent Clp protease } \\
\text { Aspartyl protease Protein } \\
\text { Protein aspartic protease in guard } \\
\text { cell }\end{array}$} & \\
\hline & \multirow{2}{*}{$\begin{array}{l}\text { AUA } 2 K \angle A I V L U \\
\text { A9PA38 }\end{array}$} & \multirow{2}{*}{$\begin{array}{l}(57.6 \%) \\
\text { Ana c } 2 \\
(77.0 \%)\end{array}$} & & \\
\hline & & & & \\
\hline & A9PBM7 & Der $\mathrm{p} 15$ & & \\
\hline & A9PCK2 & $(56.6 \%)$ & & \\
\hline & B9GJE2 & CPA63 & \multirow{3}{*}{$\begin{array}{l}\text { Aspartic protease family protein } \\
\text { Aspartyl protease family protein } \\
\text { Aspartyl protease family protein }\end{array}$} & \\
\hline & B9GR19 & \multirow{2}{*}{$\begin{array}{l}\text { CPA63 } \\
(68.5 \%)\end{array}$} & & \\
\hline & B9GWZ3 & & & \\
\hline & В9H185 & Per a 2 & \multirow{3}{*}{$\begin{array}{l}\text { Subtilisin-like protease } \\
\text { Kunitz-type protease } \\
\text { Subtilisin-like protease }\end{array}$} & \\
\hline & B9H290 & \multirow{2}{*}{$\begin{array}{l}\text { CPA63 } \\
(63.5 \%)\end{array}$} & & \\
\hline & B9HR73 & & & \\
\hline & B918Y7 & \multirow{2}{*}{$\begin{array}{l}\text { CPA63 } \\
(68.6 \%)\end{array}$} & \multirow{4}{*}{$\begin{array}{l}\text { Aspartyl protease } \\
26 \text { S protease regulatory subunit } 7 \\
\text { family protein } \\
26 \text { S protease regulatory subunit } 7 \\
\text { family protein }\end{array}$} & \\
\hline & B9IKK0 & & & \\
\hline & B9MUK8 & $(51.8 \%)$ & & \\
\hline & \multirow[t]{6}{*}{ U5GXJ8 } & $\begin{array}{l}\text { Cup s } 1 \\
(57.5 \%)\end{array}$ & & \\
\hline & & $\begin{array}{l}\text { Pen n } 13 \\
(51.7 \%)\end{array}$ & \multirow{5}{*}{ Subtilisin-like protease } & \\
\hline & & $\begin{array}{l}\text { CPA63 } \\
(62.9 \%)\end{array}$ & & \\
\hline & & $\begin{array}{l}\text { Pen n } 13 \\
(56.9 \%)\end{array}$ & & \\
\hline & & $\begin{array}{l}\text { Asp f } 1 \\
(59.6 \%)\end{array}$ & & \\
\hline & & $\begin{array}{l}\text { Pen n } 18 \\
(57.2 \%)\end{array}$ & & \\
\hline
\end{tabular}

Note: Only homologous allergen with the highest identity has been displayed.

Identity, homologous allergen in the AllergenOnline database. Sum, total potential pollen allergens identified in the family. 


\begin{tabular}{|c|c|c|c|c|}
\hline $\begin{array}{l}\text { Allergenic protein } \\
\text { family }\end{array}$ & $\begin{array}{l}\text { Protein } \\
\text { accession }\end{array}$ & Identity (\%) & Protein description & Sum \\
\hline Expansins & $\begin{array}{l}\text { A0A2K1Z7R5 } \\
\text { A9PEQ7 } \\
\text { B9H521 } \\
\text { U5FK15 } \\
\text { U5GIP5 }\end{array}$ & $\begin{array}{l}\text { Pas n } \\
1(68.1 \%) \\
\\
\text { Sorh } \\
1(55.0 \%) \\
\text { Lol p I } \\
(57.9 \%) \\
\text { Cynd } \\
1(60.8 \%) \\
\\
\text { Dac g } \\
1(65.2 \%)\end{array}$ & $\begin{array}{l}\text { Expansin-like A2 } \\
\text { Expansin family protein } \\
\text { Alpha-expansin } 11 \text { family protein } \\
\text { Expansin } \mathrm{S} 1 \text { family protein } \\
\text { Expansin-like B1 }\end{array}$ & 5 \\
\hline $\begin{array}{l}\text { Calcium-binding } \\
\text { proteins }\end{array}$ & $\begin{array}{l}\text { A9P988 } \\
\text { A9PCU6 }\end{array}$ & $\begin{array}{l}\text { Jun o } 4 \\
(69.6 \%) \\
\text { pollen } \\
\text { allergen } \\
\text { group } 2\end{array}$ & $\begin{array}{l}\text { Probable calcium-binding protein } \\
\text { Calcium-binding EF hand family } \\
\text { protein }\end{array}$ & 2 \\
\hline Inhibitory proteins & $\begin{array}{l}\text { A9P9T5 } \\
\text { B9GNE2 } \\
\text { B9GX99 } \\
\text { B9H290 } \\
\text { B9HSW8 } \\
\text { B914L9 }\end{array}$ & $\begin{array}{l}\text { Ani s } 4 \\
(64.0 \%) \\
\text { Api m } 6 \\
(79.5 \%) \\
\text { Ani s } 4 \\
(58.8 \%) \\
\text { Cry j 1(56.1\%) } \\
\text { Pla o } 1 \\
(63.3 \%) \\
\text { Ole e } 3 \\
(75.9 \%)\end{array}$ & $\begin{array}{l}\text { Cysteine proteinase inhibitor } \\
\text { Cysteine proteinase inhibitor } \\
\text { Cysteine proteinase inhibitor } \\
\text { Kunitz-type protease inhibitor } \\
\text { Cell wall / vacuolar inhibitor of } \\
\text { fructosidase } \\
\text { Invertase/pectin methylesterase } \\
\text { inhibitor family protein }\end{array}$ & 6 \\
\hline Polygalacturonase & $\begin{array}{l}\text { B9GQC0 } \\
\text { B9H9W1 }\end{array}$ & $\begin{array}{l}\text { Zea m } 13 \\
(55.4 \%) \\
\text { Cry j } 2 \\
(71.4 \%)\end{array}$ & $\begin{array}{l}\text { Polygalacturonase-like family } \\
\text { protein } \\
\text { Polygalacturonase }\end{array}$ & 2 \\
\hline
\end{tabular}

Note: Only homologous allergen with the highest identity has been displayed.

Identity, homologous allergen in the AllergenOnline database. Sum, total potential pollen allergens identified in the family. 


\begin{tabular}{|c|c|c|c|c|}
\hline $\begin{array}{l}\text { Allergenic protein } \\
\text { family }\end{array}$ & $\begin{array}{l}\text { Protein } \\
\text { accession }\end{array}$ & Identity (\%) & Protein description & Sum \\
\hline \multirow{16}{*}{$\begin{array}{l}\text { Heat shock protein } \\
70\end{array}$} & B9GEL5 & \multirow{2}{*}{$\begin{array}{l}\text { Alt a } 3 \\
(62.6 \%)\end{array}$} & Heat shock protein 70 & \multirow[t]{16}{*}{12} \\
\hline & B9GJ14 & & Heat shock protein 70 & \\
\hline & $\mathrm{A} 0 \mathrm{~A} 2 \mathrm{~K} 1 \mathrm{XBF} 6$ & $\begin{array}{l}\text { Der p } 28 \\
(77.4 \%)\end{array}$ & Activator of $90 \mathrm{kDa}$ heat shock & \\
\hline & B9HMG2 & $\begin{array}{l}\text { Cor a } 1 \\
(49.6 \%)\end{array}$ & Heat shock protein 70 & \\
\hline & B9HMG7 & \multirow{2}{*}{$\begin{array}{l}\text { Pen c } 19 \\
(90.1 \%)\end{array}$} & Heat shock protein 70 cognate & \\
\hline & B9HMG8 & & Heat shock protein 70 cognate & \\
\hline & B9HN74 & $\begin{array}{l}\text { Pen c } 19 \\
(88.7 \%)\end{array}$ & Heat shock protein 70 & \\
\hline & & \multirow{2}{*}{$\begin{array}{l}\text { Pen c } 19 \\
(91.6 \%)\end{array}$} & Heat shock protein 70 & \\
\hline & B9HV59 & & Heat shock protein 70 & \\
\hline & & $\begin{array}{l}\text { Pen c } 19 \\
(78.1 \%)\end{array}$ & Heat shock protein 70 cognate & \\
\hline & \multirow{6}{*}{ B9NBF4 } & \multirow{2}{*}{$\begin{array}{l}\text { Pen c } 19 \\
(90.6 \%)\end{array}$} & Heat shock protein 70 cognate & \\
\hline & & & Heat shock protein 70 cognate & \\
\hline & & $\begin{array}{l}\text { Pen c } 19 \\
(70.9 \%)\end{array}$ & & \\
\hline & & $\begin{array}{l}\text { Der p } 28 \\
(88.2 \%)\end{array}$ & & \\
\hline & & $\begin{array}{l}\text { Pen c } 19 \\
(90.0 \%)\end{array}$ & & \\
\hline & & $\begin{array}{l}\text { Pen c } 19 \\
(91.8 \%)\end{array}$ & & \\
\hline Note: Only homolog & s allergen with & e highest iden & has been displayed. & \\
\hline $\begin{array}{l}\text { Identity, homologou } \\
\text { identified in the fam }\end{array}$ & ergen in the $A$ & genOnline d & se. Sum, total potential pollen & \\
\hline
\end{tabular}

\section{Screening of potential allergens in the Hsp70 protein family}

All the Hsp70s were checked, and B9N9W6 was selected as a potential allergen to elicit host immune response due to its physical and chemical characteristics as follows. IEDB epitope prediction showed that had 3 T-cell epitopes and 4 B-cell epitopes with high affinity (Table 2, 3). The formula of B9N9W6 was $\mathrm{C}_{3146} \mathrm{H}_{5062} \mathrm{~N}_{880} \mathrm{O}_{1001} \mathrm{~S}_{21}$, MW was 71900 , PI was 5.34, and antigenicity was 0.5714 (Threshold >0.4), which was considered as a stable hydrophilic protein. Query through AllergenOline database showed that B9N9W6 had a conserved Hsp70 domain. Protein homology analysis revealed that the Hsp70 family protein sequences were extremely conserved (Fig. 5). Secondary structure of B9N9W6 was dominated by 
a-helix and $\beta$ ladder (Fig. 6), and it might be a hetero-dimer according to the crystal structure on the surface (Fig. 7).

Table 2

Prediction of T cell epitopes in B9N9W6

\begin{tabular}{|lcc|}
\hline Epitope peptide & IC $_{50}$ (SMM) & IC $_{50}(\mathrm{NN})$ \\
\hline QDLLLLDVTPLSVGI & 25 & 21.2 \\
\hline LNVLRIINEPTAAAI & 99 & 19.1 \\
LRIINEPTAAAIAYG & 176 & 34.5 \\
\hline $\begin{array}{l}\text { Note: The predicted output is given in units of } \mathrm{IC}_{50} \mathrm{nM} \text { for Stabilized Matrix Method (SMM) and } \\
\text { Neutral-Network (NN) scoring. The lower number indicates higher affinity. Peptides with } \mathrm{IC}_{50} \text { values }< \\
50 \text { nM are considered high affinity. }\end{array}$ \\
\hline
\end{tabular}

Table 3

Prediction of B cell epitopes in B9N9W6

\section{Epitope peptide}

GRRFSDPSVQSDMKHWPF

KASGVKNKITITNDKGRLGKDDIERMVQEAERYKAEDEKVKKKVEAKNA

NTVRDDKVGGKLDPADKQKIEKEIEETIDWLDRNQLAEVDEFEDK

QGAGGDVPMGGGAQMPGGAYSKASSGGSGAGPKI

Note: Bepipred Linear Epitope Prediction 2.0 was selected to predict the B cell Epitope, which analyzed the sequence characteristics of antigen and used the size of amino acid residues to predict the $B$ cell epitopes.

\section{Protein expression and purification of B9N9W6}

SDS-PAGE of B9N9W6 showed specific band with a MW at 70KD, and purified product showed a clear band at same position (Fig. 8). His-tag detection revealed that the protein purity was more than $90 \%$.

\section{B9N9W6 induced antibody and cytokine responses}

In order to explore the effects of B9N9W6 on serum antibodies and cytokines, the levels of IgE and cytokine IL-4 in serum were detected by ELISA kit. The results were showed in Fig. 9. The IgE level in the extract group $(13.83 \pm 5.59 \mathrm{ng} / \mathrm{mL})$ was significantly higher than that in the PBS group $(7.58 \pm 2.40$ $\mathrm{ng} / \mathrm{mL}, P<0.05)$, but significantly lower than that in B9N9W6 group $(25.76 \pm 11.90) \mathrm{ng} / \mathrm{mL}, P<0.01)$. In terms of IL-4 level, the IL-4 level in the extract group $(120.08 \pm 36.58 \mathrm{pg} / \mathrm{mL})$ was higher than that in the PBS group $(74.69 \pm 25.30 \mathrm{pg} / \mathrm{mL}, P<0.05)$, while the IL-4 level in the B9N9W6 group $(255.24 \pm 81.88$ $\mathrm{pg} / \mathrm{mL})$ was the highest among all groups $(P<0.01)$. 


\section{B9N9W6 induced CD4 ${ }^{+} \mathrm{T}$ cell proliferation and Th2 differentiation}

In order to evaluate the ability of B9N9W6 to stimulate the proliferation of $\mathrm{CD} 4^{+} \mathrm{T}$ cells, we detected the number of proliferating $\mathrm{CD} 4^{+} \mathrm{T}$ cells and their subsets by flow cytometry. The results showed that compared with the PBS group (12.84 $\pm 0.53 \%$ ) and extract group (18.10 $\pm 0.58 \%)$, B9N9W6 significantly promoted the proliferation of $\mathrm{CD} 4^{+} \mathrm{T}$ cells $(27.86 \pm 1.07 \%, P<0.01)$ (Fig. 10A, C1). Compared with the PBS group (2.39 \pm 0.34$)$, the ratio of Th1/Th2 in extract group (1.75 \pm 0.24$)$ and B9N9W6 group (1.69 \pm 0.21 ) had significantly lower $(P<0.01)$ (Fig. 10B, C2).

\section{B9N9W6 induced allergic inflammation in the lung tissue of mice models}

Compared with the PBS group, the extract group showed reduced lung tissue alveoli due to destroyed anatomical structure, and increased mucus in the respiratory bronchus (Fig. 11B). A large number of inflammatory cells were exudated to the lung field. Alveolar septum thickens due to edema while mucus and inflammatory cells appeared in the terminal bronchioles and its periphery (Fig. 11E, H). Compared with the extract group, a mass of red blood cells exudate was found in the B9N9W6 group, and the destruction of alveoli was further aggravated (Fig. 11C); Bullae formed, the collapsed alveolar cavity and exudate of erythrocyte were detected; Mucus and inflammatory cells were abundant in the terminal bronchioles (Fig. 11F, I).

\section{Discussion}

In recent years, allergic diseases caused by pollens have attracted much attention, especially in the plant species releasing pollens, specific IgE reactivity and the influence of air pollutants on pollen transmission [21-23]. Nevertheless, identification of allergenic proteins and their bioactivity have remained elusive. In this study, we detected 3929 distinct proteins in pollen of $P$. deltoides by proteomics. We performed systematic bioinformatics analysis of all identified proteins, including protein annotation, functional classification and functional enrichment. Through functional annotation, we found that the total proteins of $P$. deltoides pollen and $P$. tomentosa pollen have great difference in function [14]. By GO categorization, we found that the total proteins of $P$. deltoides pollen were significantly different from those of its two mutants in biological process, molecular function, and cellular component [12]. KEGG enrichment analysis indicated that these identified proteins were not only involved in organelle composition and biogenesis, but also in biological processes such as metabolism and synthesis. There are great differences in the ingredients and functions of pollen proteins among different species of the same genus, which provides a material basis for antigen screening.

Plant-derived allergens mainly belong to disease-related protein 10 (DRP-10), thomas protein-like protein (TLP), Non-specific lipid transfer proteins (nsLTPs), expansion proteins, calcium binding proteins and profilin protein families $[24,25]$. These proteins are called pan-allergen in specialized terms such as 
profilin, because the same family of proteins has a common antigenic determinant, and they can cause a wide range of cross-reactions [26]. Proteins of the same family share a common domain and are relatively conservative in structure, which caused the common allergen proteins can be identified in a variety of plants [27-29]. In this study, through sequence alignment in the database, we identified 49 potential allergens belonging to 10 protein families. The protease family and the Hsp70 family are the most abundant. These results indicated that $P$. deltoides pollen not only contained abundant protein components, but also easily had fruit-vegetable-pollen cross-reactive allergy syndromes.

Hsp represent a family of molecular chaperones that response to refolding proteins, protein trafficking, and cell signaling processes [30-32]. Hsp 70 is an important member of the Hsp family involved in stress response, which often used as a potential biomarker, therapeutic target, or modulator of inflammation [33, 34]. Furthermore, Hsp 70 is also involved leaf remodeling, flowering and disease resistance in plant [3537]. A correlation between biological function and allergenic capacity of proteins related to stress response has not been clearly demonstrated. Studies had shown that luminal binding protein of Hsp 70 family in hazel pollen is a cross-reactive allergen [17]. C-terminal region of Hsp 70 of Echinococcus Granulosus is antigenic molecule inducing both B and T cell responses [15]. Coincidentally, a large number of proteins and potential allergens containing the Hsp70 domain were identified in this study, such as B9N9W6. Epitope prediction suggested that B9N9W6 might have antigenic activity. Sequence alignment showed that B9N9W6 was highly consistent with the amino acid sequences of known allergens Cla h 4, Der f 28, etc. Homology modeling for B9N9W6 found that its 3-dimensional structure was also highly similar which consists of two main useful realms separated by a hinge region (Fig. 6A, and 6B); which accorded with the structural characteristics of the Hsp70 family [38]. This remarkable conservation of both surface residues and main chain conformations in the Hsp 70 family plays an important role in conservation of IgE-binding epitopes[39].

Identification and purification of pollen allergens is of great significance both for the study of crossallergic reaction and AIT. The immunoreactivity of Hsp 70 had been demonstrated in previous studies [17, $39,40]$. In this study, the bioactivity of B9N9W6 was detected by animal model. First, we demonstrated that B9N9W6 can stimulate the immune system to produce high levels of IgE antibodies and promote the production of IL-4 via ELISA. Allergen specific IgE antibody is a major cause of type I allergic diseases, such as asthma [41], IL-4 is an important proinflammatory factor secreted by Th2 cells to mediate allergic airway inflammation [42]. Meanwhile, the significant increase of IL-4 concentration in the B9N9W6 group indicated the imbalance of Th1/Th2 cells and the increase of Th2 cells. Secondly, we detected the proliferation of B9N9W6 to stimulate $\mathrm{CD} 4^{+} \mathrm{T}$ cells and their subgroup Th1/Th2 cells by flow cytometry. It was found that B9N9W6 could significantly stimulate $\mathrm{CD} 4^{+} \mathrm{T}$ cell proliferation and promote $\mathrm{Th} 2$ cell polarization. These results suggested an immunogenicity of B9N9W6, which were consistent with ELISA. All above results suggest that B9N9W6 may induce allergic inflammation in the airway of the mice model. To verify our hypothesis, the presence of inflammation was observed through H\&E staining sections of the mice lung tissues. More inflammatory cells infiltration and mucus exudation were observed in the lung tissue of B9N9W6 group; the alveolar rupture was the most serious, and even caused 
pulmonary hemorrhage. Therefore, we consider that under the same concentration, the sensitization of B9N9W6 was stronger than that of extract. There are three possible reasons for this result: 1) B9N9W6 might have a dominant T/B cell epitope, which can strongly stimulate the immune response (Table 2, 3). 2) As a member of the Hsp 70 family, B9N9W6 could enhance the activity of antibody-presenting cells (APCs) in the process of antigen processing and presentation, which is essential for the initiation and modulation of the asthmatic immune response [43]. 3) Hsp 70 is a positive regulator of airway inflammation and goblet cell hyperplasia in allergic airway inflammation [44]; the pathological findings of this study supported this view. Therefore, our findings suggested that B9N9W6 potentially induces allergen induced Th2 inflammatory responses.

\section{Conclusions}

In summary, This study empolyed the proteomics method to screen out 49 allergens from 10 protein families of $P$. deltoides pollen. Furthermore, B9N9W6 protein of HSP70 family was confirmed to has strong allergen activity and can induce allergic asthma in animal models. Our conclusions not only enrich the theoretical study of Hsp70 family in pollen allergens, but also provide reference for the study of crossallergic reaction and immunotherapy of allergic diseases. In the future, we will focus on several candidate allergens that occured in KEGG enrichment analysis, especially in Hsp70 mediated signaling pathways.

\section{Abbreviations}

Hsp: Heat shock protein; AIT: Allergen immunotherapy; DRP-10: Disease-related protein 10; TLP: Thomas protein-like protein; nsLTPs: Non-specific lipid transfer proteins; SPF: Specific pathogen free; GO: Gene Ontology; KEGG: Kyoto Encyclopedia of Gnens and Genomes

\section{Declarations}

\section{Statement of Ethics}

This study was conducted in strict accordance with the proposals of the Guide for the Care and Use of Laboratory Animals of the National Institutes of Health, and the mouse in this study were reviewed and approvednimal by the Institutional A Care and Use Committee of Hangzhou Hibio Technology Co.Ltd. (IACUC protocol number: HBFM3.68-2015). The pollen of $P$. deltoides used in this study were conducted in strict accordance with the Convention on Biological Diversity and the Convention on the Trade in Endangered Species of Wild Fauna and Flora.

\section{Availability of data and materials}

The datasets used and analyzed during the current study are available from the corresponding author upon reasonable request.

\section{Disclosure Statement}


The authors declare that they have no conflict of interest.

\section{Funding Sources}

This study was supported by National Natural Science Foundation of China, Grant Number 31971562.

\section{Author Contributions}

Wei Guo and Yilong Xi conceived the idea and wrote the manuscript. Xiaodong Zhan depicted figures and analyzed data. Feng Jiang contributed for revision. Yilong Xi contributed for overall editing and supervision. All authors approved its submission.

\section{Acknowledgement}

We would like to thank Hangzhou Hibio Technology Co. Ltd. for providing us with the SPF animal room and flow cytometer for this study.

\section{References}

1. Schatz M, Rosenwasser L, The allergic asthma phenotype. J Allergy Clin Immunol Pract 2014, 2, (6), 645-8; quiz 649.

2. Cevhertas L, Ogulur I, Maurer DJ, Burla D, Ding M, Jansen K, Koch J, Liu C, Ma S, Mitamura Y, Peng Y, Radzikowska U, Rinaldi AO, Satitsuksanoa P, Globinska A, van de Veen W, Sokolowska M, Baerenfaller K, Gao YD, Agache I, Akdis M, Akdis CA. Advances and recent developments in asthma in 2020. Allergy. 2020;75(12):3124-46.

3. Stern J, Pier J, Litonjua AA. Asthma epidemiology and risk factors. Semin Immunopatho/ 2020, 42, (1), 5-15.

4. Pakkasela J, Ilmarinen P, Honkamaki J, Tuomisto LE, Andersen H, Piirila P, Hisinger-Molkanen $H$, Sovijarvi A, Backman H, Lundback B, Ronmark E, Kankaanranta H, Lehtimaki L. Age-specific incidence of allergic and non-allergic asthma. BMC Pulm Med. 2020;20(1):9.

5. Poowuttikul P, Saini S, Seth D. Inner-City Asthma in Children. Clin Rev Allergy Immunol. 2019;56(2):248-68.

6. Galli SJ, Tsai M, Piliponsky AM. The development of allergic inflammation. Nature 2008, 454, (7203), 445-54.

7. Rachmiel M, Bloch O, Bistritzer T, Weintrob N, Ofan R, Koren-Morag N, Rapoport MJ. TH1/TH2 cytokine balance in patients with both type 1 diabetes mellitus and asthma. Cytokine. 2006;34(34):170-6.

8. Ying L, Fu Z, Luo J, Zhou C, Chen Y, Wang L, Liu E. Cytotoxic T lymphocyte antigen 4 immunoglobulin modified dendritic cells attenuate allergic airway inflammation and hyperresponsiveness by regulating the development of T helper type 1 (Th1)/Th2 and Th2/regulatory T cell subsets in a murine model of asthma. Clin Exp Immunol. 2011;165(1):130-9. 
9. Camacho I, Caeiro E, Nunes C, Morais-Almeida M. Airborne pollen calendar of Portugal: a 15-year survey (2002-2017). Allergol Immunopathol (Madr) 2020, 48, (2), 194-201.

10. Pablos I, Eichhorn S, Briza P, Asam C, Gartner U, Wolf M, Ebner C, Bohle B, Arora N, Vieths S, Ferreira F, Gadermaier G. Proteomic profiling of the weed feverfew, a neglected pollen allergen source. Sci Rep 2017, 7, (1), 6049.

11. Fu W, Gao Z, Gao L, Jin J, Liu M, Sun Y, Wu S, Wu L, Ma H, Dong Y, Wang X, Gao B, Wang H, Akkerdaas JH, Versteeg SA, van Ree R. Identification of a 62-kDa major allergen from Artemisia pollen as a putative galactose oxidase. Allergy. 2018;73(5):1041-52.

12. Zhang XL, Zhang J, Guo YH, Sun P, Jia HX, Fan W, Lu MZ, Hu JJ, Comparative Proteomic Analysis of Mature Pollen in Triploid and Diploid Populus deltoides. Int J Mol Sci 2016, 17, (9).

13. Zhang J, Wu LS, Fan W, Zhang XL, Jia HX, Li Y, Yin YF, Hu JJ, Lu MZ. Proteomic analysis and candidate allergenic proteins in Populus deltoides CL. "2KEN8" mature pollen. Front Plant Sci. 2015;6:548.

14. Wang L, Zhang X, Zhang J, Fan W, Lu M, Hu J, Proteomic Analysis and Identification of Possible Allergenic Proteins in Mature Pollen of Populus tomentosa. Int J Mol Sci 2018, 19, (1).

15. Ortona E, Margutti P, Delunardo F, Vaccari S, Rigano R, Profumo E, Buttari B, Teggi A, Siracusano A. Molecular and immunological characterization of the $C$-terminal region of a new Echinococcus granulosus Heat Shock Protein 70. Parasite Immunol 2003, 25, (3), 119 - 26.

16. Min HJ, Kim KS, Yoon JH, Kim CH, Cho HJ. T-helper 2 cytokine-induced heat shock protein 70 secretion and its potential association with allergic rhinitis. Int Forum Allergy Rhinol. 2017;7(5):5305.

17. Gruehn S, Suphioglu C, O'Hehir RE, Volkmann D. Molecular cloning and characterization of hazel pollen protein $(70 \mathrm{kD})$ as a luminal binding protein (BiP): a novel cross-reactive plant allergen. Int Arch Allergy Immunol. 2003;131(2):91-100.

18. Feng J, Wu Z, Wang X, Zhang Y, Teng N, Analysis of Pollen Allergens in Lily by Transcriptome and Proteome Data. Int J Mol Sci 2019, 20, (23).

19. San Segundo-Acosta P, Oeo-Santos C, Benede S, de Los Rios V, Navas A, Ruiz-Leon B, Moreno C, Pastor-Vargas C, Jurado A, Villalba M, Barderas R. Delineation of the Olive Pollen Proteome and Its Allergenome Unmasks Cyclophilin as a Relevant Cross-Reactive Allergen. J Proteome Res. 2019;18(8):3052-66.

20. Xu F, Yu S, Qin M, Mao Y, Jin L, Che N, Liu S, Ge R, Hydrogen-Rich Saline Ameliorates Allergic Rhinitis by Reversing the Imbalance of Th1/Th2 and Up-Regulation of CD $4+$ CD25 + Foxp3 + Regulatory T Cells, Interleukin-10, and Membrane-Bound Transforming Growth Factor-beta in Guinea Pigs. Inflammation 2018, 41, (1), 81-92.

21. Wang $X$, Guo $M$, Wang $H$, Wang $X$. [Pollen allergen sensitization feature of seasonal allergic rhinitis in children and adolescents in northern China]. Lin Chung Er Bi Yan Hou Tou Jing Wai Ke Za Zhi. 2020;34(11):1005-10. 
22. Scevkova J, Vaskova Z, Sepsiova R, Dusicka J, Kovac J. Relationship between Poaceae pollen and $\mathrm{Phl}$ p 5 allergen concentrations and the impact of weather variables and air pollutants on their levels in the atmosphere. Heliyon 2020, 6, (7), e04421.

23. Sabit M, Wong C, Andaya A, Ramos JD. Pollen allergen skin test and specific IgE reactivity among Filipinos: a community-based study. Allergy Asthma Clin Immunol. 2020;16:74.

24. Breiteneder $\mathrm{H}$, Ebner $\mathrm{C}$. Molecular and biochemical classification of plant-derived food allergens. $\mathrm{J}$ Allergy Clin Immunol. 2000;106(1 Pt 1):27-36.

25. Radauer $\mathrm{C}$, Breiteneder $\mathrm{H}$. Pollen allergens are restricted to few protein families and show distinct patterns of species distribution. J Allergy Clin Immunol. 2006;117(1):141-7.

26. Sircar G, Bhowmik M, Sarkar RK, Najafi N, Dasgupta A, Focke-Tejkl M, Flicker S, Mittermann I, Valenta R, Bhattacharya K, Gupta Bhattacharya S. Molecular characterization of a fungal cyclophilin allergen Rhi o 2 and elucidation of antigenic determinants responsible for IgE-cross-reactivity. J Biol Chem. 2020;295(9):2736-48.

27. Subbarayal B, Schiller D, Mobs C, de Jong NW, Ebner C, Reider N, Bartel D, Lidholm J, Pfutzner W, Gerth van Wijk, R, Vieths S, Bohle B. Kinetics, cross-reactivity, and specificity of Bet v 1-specific IgG4 antibodies induced by immunotherapy with birch pollen. Allergy. 2013;68(11):1377-86.

28. Hofmann C, Scheurer S, Rost K, Graulich E, Jamin A, Foetisch K, Saloga J, Vieths S, Steinbrink K, Adler HS. Cor a 1-reactive T cells and IgE are predominantly cross-reactive to Bet $v 1$ in patients with birch pollen-associated food allergy to hazelnut. J Allergy Clin Immunol. 2013;131(5):1384-92 e6.

29. Fernandez Rivas M. [Cross-reactivity between fruit and vegetables]. Allergol Immunopathol (Madr) 2003, 31, (3), 141-6.

30. Zininga T, Ramatsui L, Shonhai A. Heat Shock Proteins as Immunomodulants. Molecules 2018, 23, (11).

31. Bolhassani A, Agi E. Heat shock proteins in infection. Clin Chim Acta. 2019;498:90-100.

32. Tukaj S, Heat Shock Protein 70 as a Double Agent Acting Inside and Outside the Cell: Insights into Autoimmunity. Int J Mol Sci 2020, 21, (15).

33. Elmallah MIY, Cordonnier M, Vautrot V, Chanteloup G, Garrido C, Gobbo J. Membrane-anchored heatshock protein 70 (Hsp70) in cancer. Cancer Lett. 2020;469:134-41.

34. Shevtsov M, Huile G, Multhoff G. Membrane heat shock protein 70: a theranostic target for cancer therapy. Philos Trans R Soc Lond B Biol Sci 2018, 373, (1738).

35. Gorovits R, Moshe A, Ghanim M, Czosnek H. Recruitment of the host plant heat shock protein 70 by Tomato yellow leaf curl virus coat protein is required for virus infection. PLoS One 2013, 8, (7), e70280.

36. Chen X, Shi L, Chen Y, Zhu L, Zhang D, Xiao S, Aharoni A, Shi J, Xu J. Arabidopsis HSP70-16 is required for flower opening under normal or mild heat stress temperatures. Plant Cell Environ. 2019;42(4):1190-204. 
37. Rowarth NM, Dauphinee AN, Denbigh GL, Gunawardena AH. Hsp70 plays a role in programmed cell death during the remodelling of leaves of the lace plant (Aponogeton madagascariensis). J Exp Bot. 2020;71(3):907-18.

38. Lu RC, Tan MS, Wang H, Xie AM, Yu JT, Tan L. Heat shock protein 70 in Alzheimer's disease. Biomed Res Int. 2014;2014:435203.

39. Chiung YM, Lin BL, Yeh CH, Lin CY. Heat shock protein (hsp 70)-related epitopes are common allergenic determinants for barley and corn antigens. Electrophoresis. 2000;21(2):297-300.

40. Shen HD, Au LC, Lin WL, Liaw SF, Tsai JJ, Han SH. Molecular cloning and expression of a Penicillium citrinum allergen with sequence homology and antigenic crossreactivity to a hsp 70 human heat shock protein. Clin Exp Allergy. 1997;27(6):682-90.

41. Shokouhi Shoormasti R, Fazlollahi MR, Kazemnejad A, Tayebi B, Nadali F, Sharif Shoushtari M, Khandan Alamdari S, Moslemi M, Movehdi M, Mari A, Pourpak Z, Moin M. IgE Sensitization to Inhalant Allergens and Its Association with Allergic Diseases in Adults. Iran J Allergy Asthma Immunol. 2018;17(2):123-33.

42. Wang X, Xu C, Ji J, Cai Y, Shu Y, Chao Y, Wu X, Zou C, Wu X, Tang L. IL-4/IL-13 upregulates Sonic hedgehog expression to induce allergic airway epithelial remodeling. Am J Physiol Lung Cell Mol Physiol 2020, 318, (5), L888-L899.

43. Bertorelli G, Bocchino V, Zhuo X, Chetta A, Del Donno M, Foresi A, Testi R, Olivieri D. Heat shock protein 70 upregulation is related to HLA-DR expression in bronchial asthma. Effects of inhaled glucocorticoids. Clin Exp Allergy. 1998;28(5):551-60.

44. Yombo DJK, Mentink-Kane MM, Wilson MS, Wynn TA, Madala SK. Heat shock protein 70 is a positive regulator of airway inflammation and goblet cell hyperplasia in a mouse model of allergic airway inflammation. J Biol Chem. 2019;294(41):15082-94.

\section{Figures}

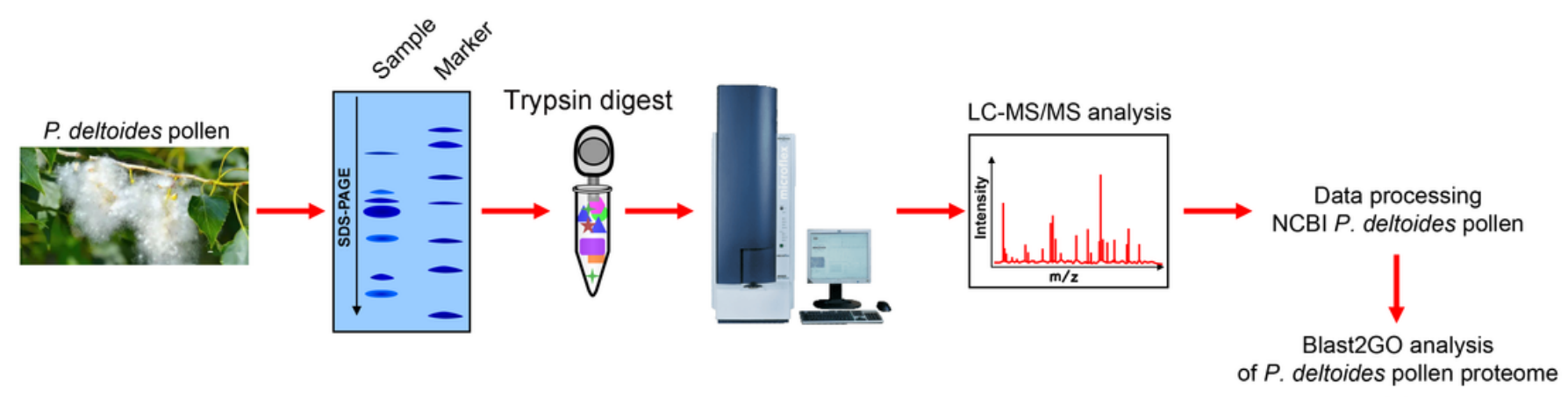

Bioactivity analysis $\longleftarrow$ Cloning and expression Identification of allergen families and potential allergens BLASTP against Allergome Uniprot database

\section{Figure 1}

Workflow of the study to delineate the P. deltoides pollen proteome and analyze its bioactivity. 

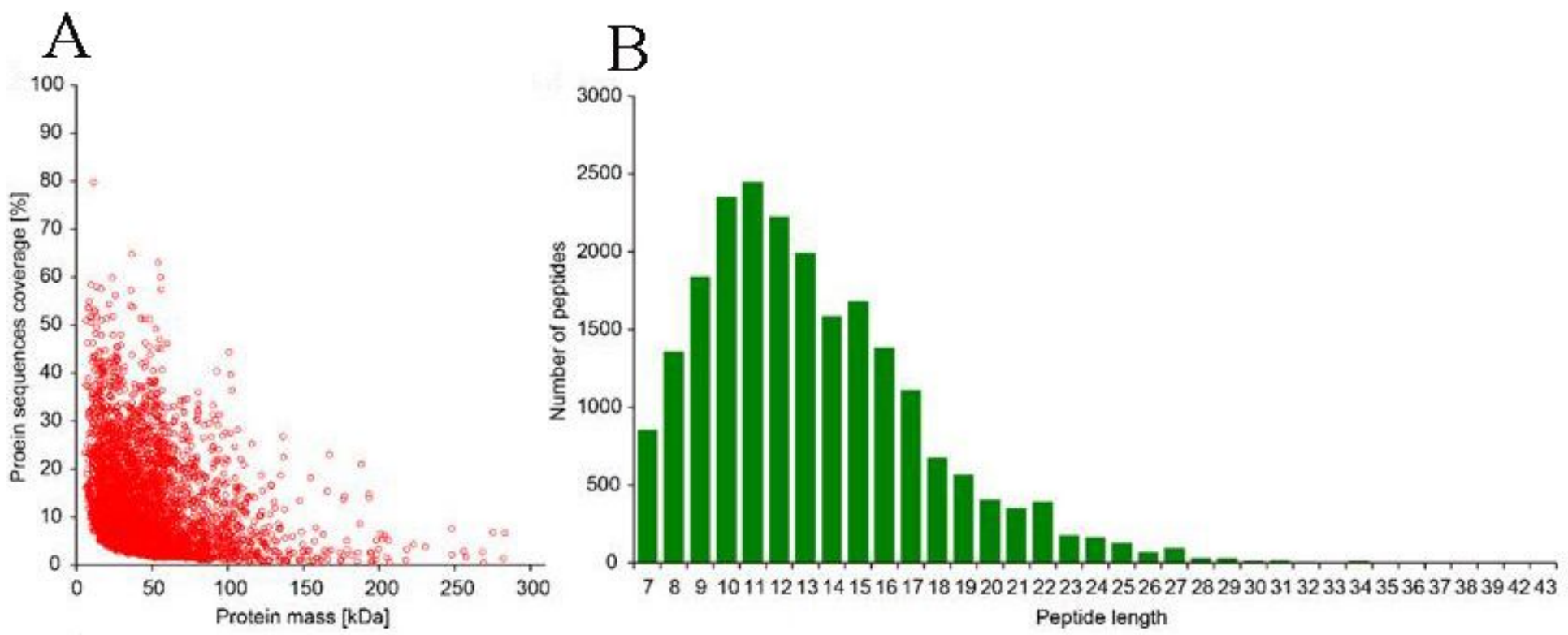

Figure 2

The characteristics of peptides in the proteome of P. deltoides pollen. A: Molecular weight and coverage.

B: Length distribution.

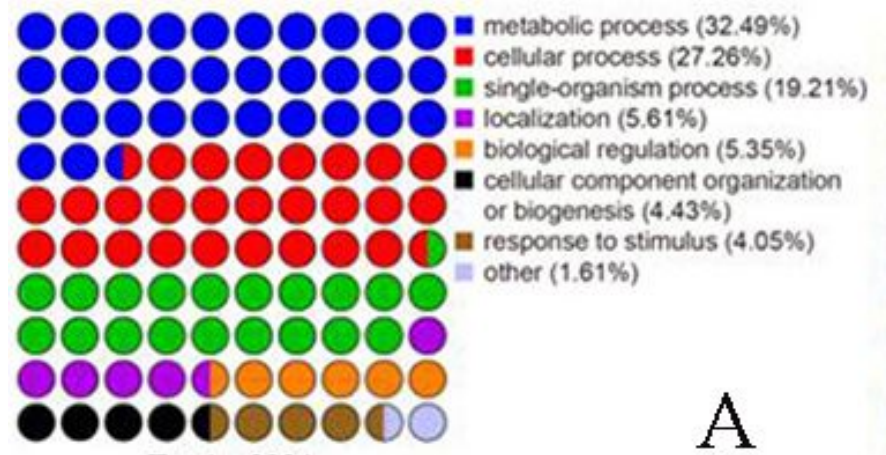

Total $=6024$
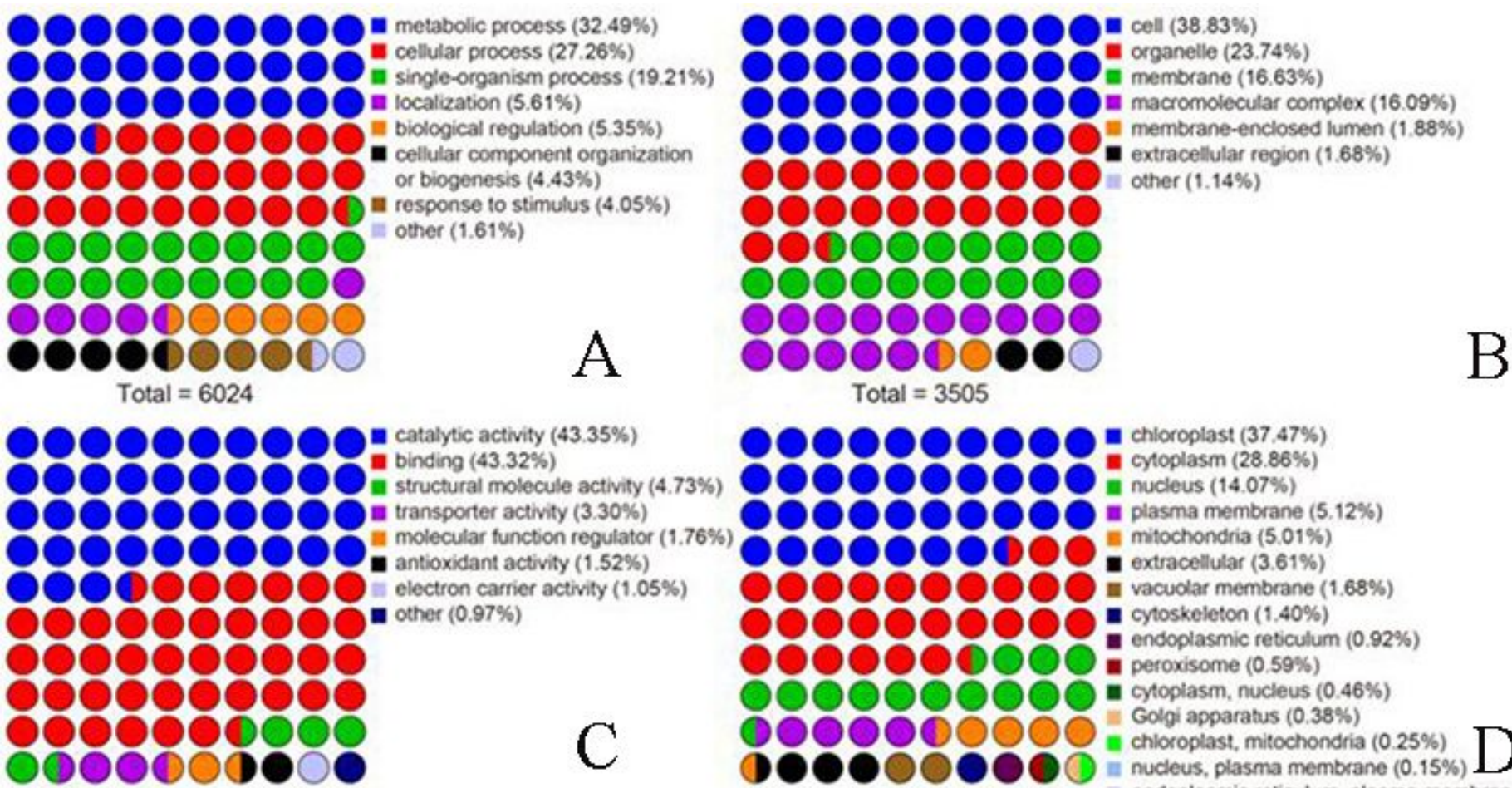

Total $=4268$

Total $=3505$

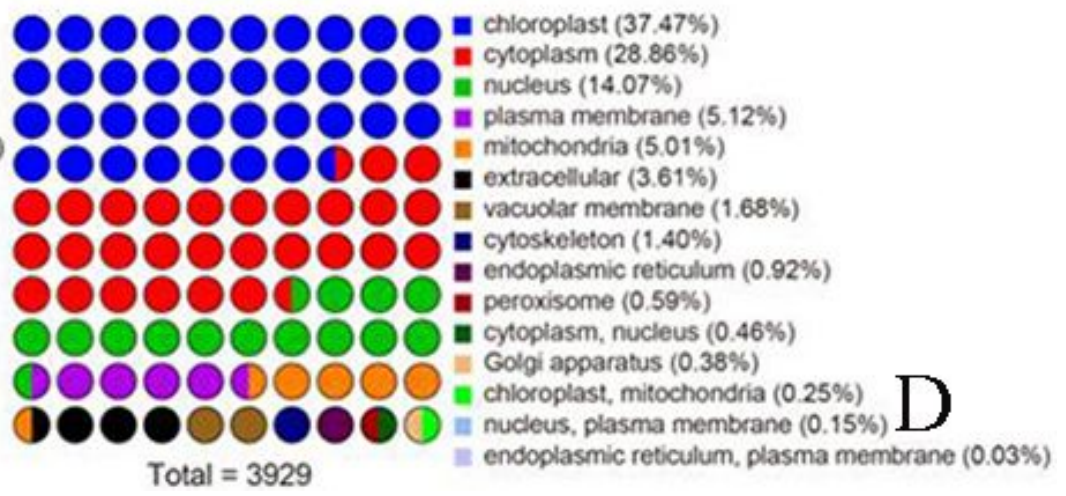

Total $=3929$

Figure 3

Gene ontology analysis of identified proteins. A: Biological process. B: Cellular components. C: Molecular function. D: Subcellular location. 


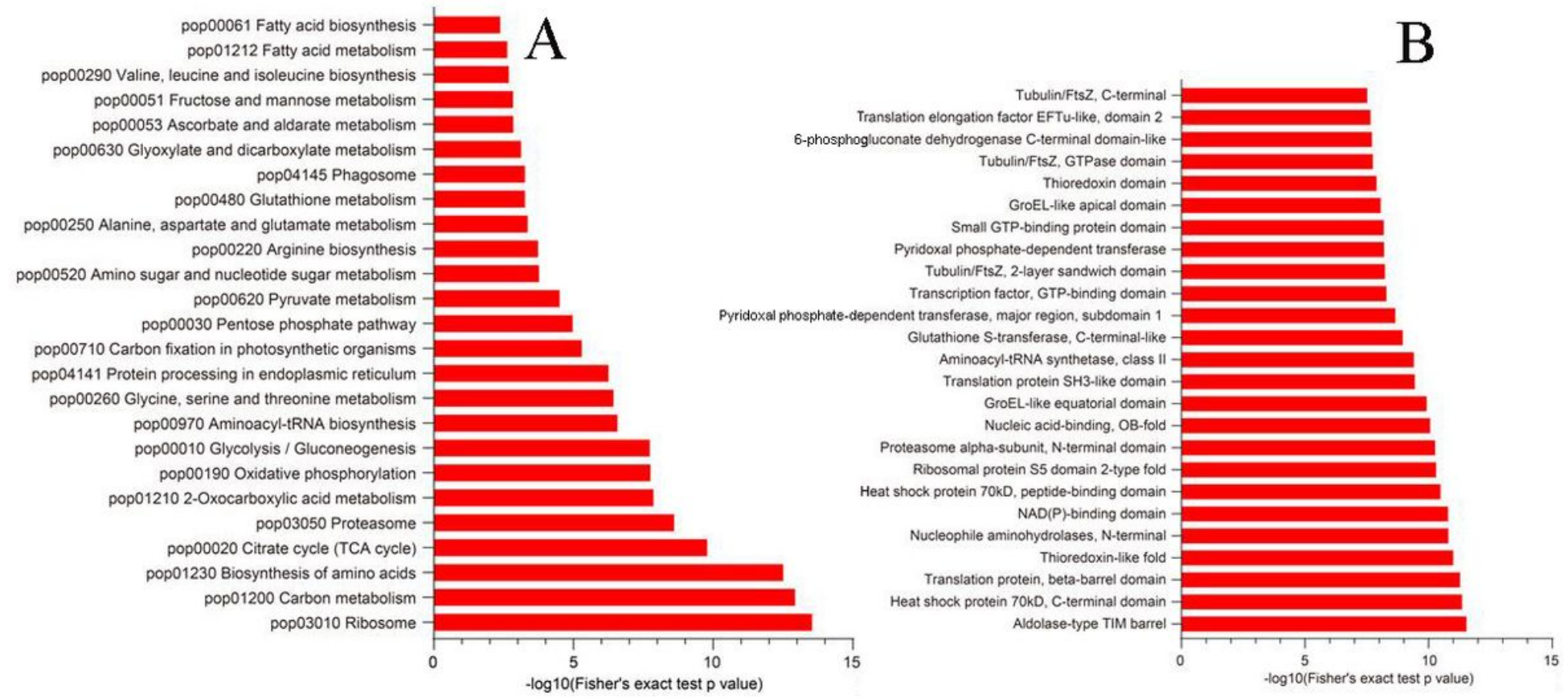

Figure 4

Enrichment analysis of the KEGG signaling pathway (A) and domains contained of peptides (B) in the P. deltoides pollen. The value of the horizontal axis is the negative log transformation of the significant $P$ value $(P<0.05)$.

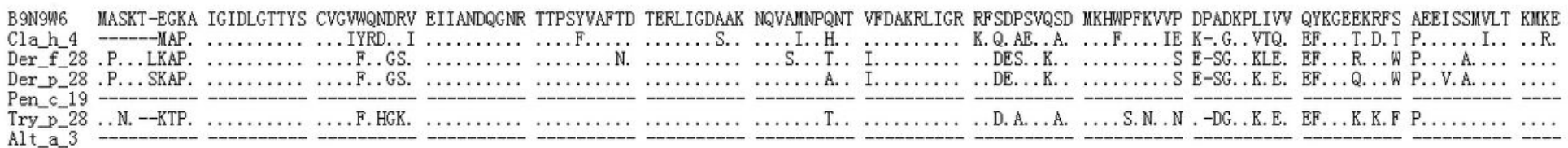

B9N9W6 IAEAYLGHAV NNAVVTVPAY FNDSQRQATK DAGAIAGLNV LRIINEPTAA AIAYGLDKKA SKSGEQNVLI FDLGGGTFDV SLLTIEEGIF EVKATAGDTH LGGEDFDNRL MNHFVAEFRR KHKKDISANA KALR Cla_h_4
Ter_f

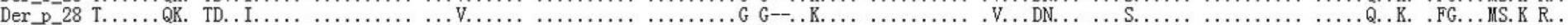

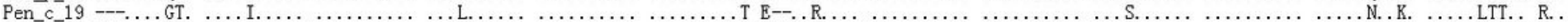

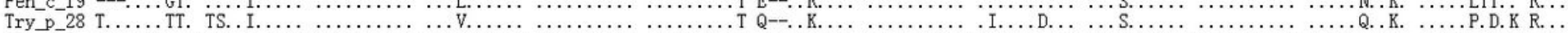

B9N9W6 RLRTACERAK RTLSSTTQTT IEIDSLYEGI DFYSTITRAR FEEMNIDLFR RCMEPVEKCL RDAKIDKSHV HEIVLVGGST RIPKVQQLLQ DFFNGKELCK SINPDEAVAY GAAVQAAILS GEGNEK-VQD LLLL

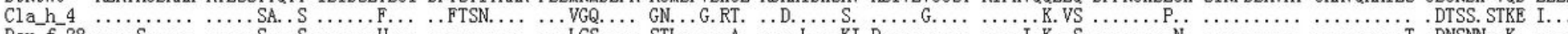

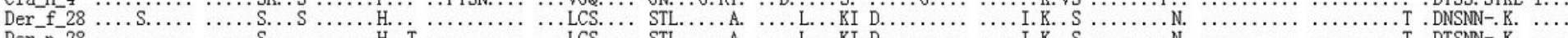

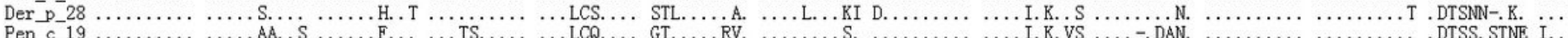

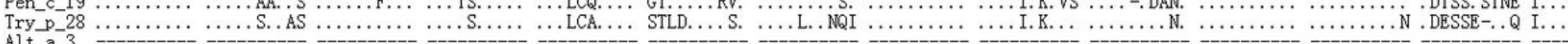

B9N9W6 DVTPLSVGIE TAGGVITVLI PRNTTIPTKK EQVFSTYSDN QTSVIQVYE GERAQTKDNN LLGTFELKGI PPAPRGVPQI NVCFDIDANG ILNVSAEDKA SGVKNKITIT NDKGRLGKDD IERNVQEAER YKAE

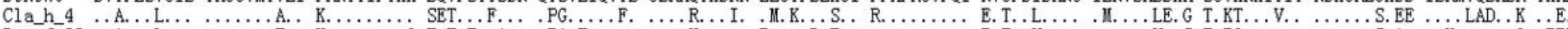

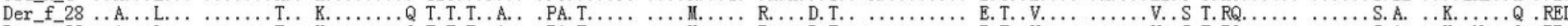

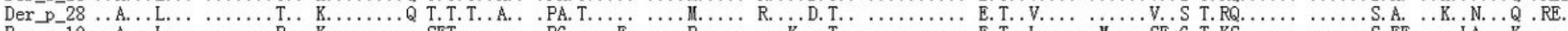

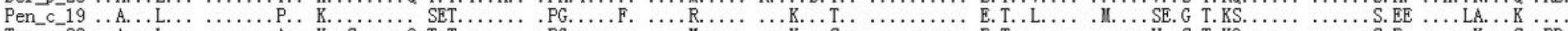

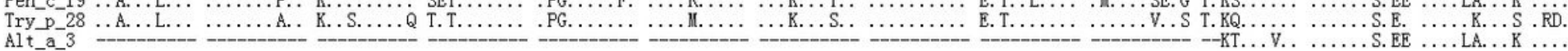

B9N9W6 DEKVKKKVEA KNALENYAYN IRRTVRDDKV GGKLDPADKQ KIEKEIEETI DWLDRNQLAE VDEFEDKLKE LEGLCNPIIS KMYQGAGGD- ---VPIIGG-- ---GAQMPGG AYSKASSGGS GAGPKIEEVD

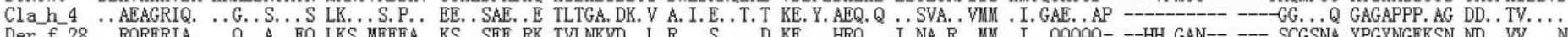

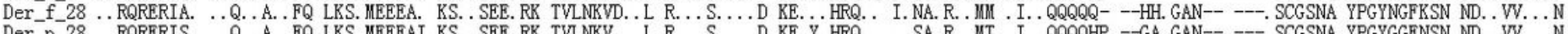

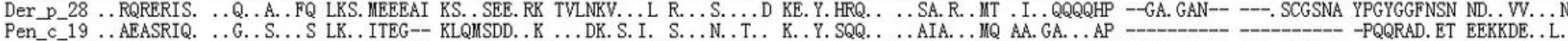

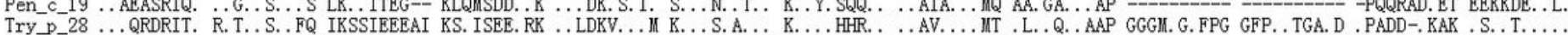

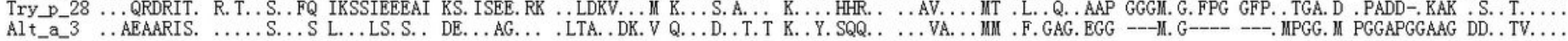

\section{Figure 5}


represented no amino acids.
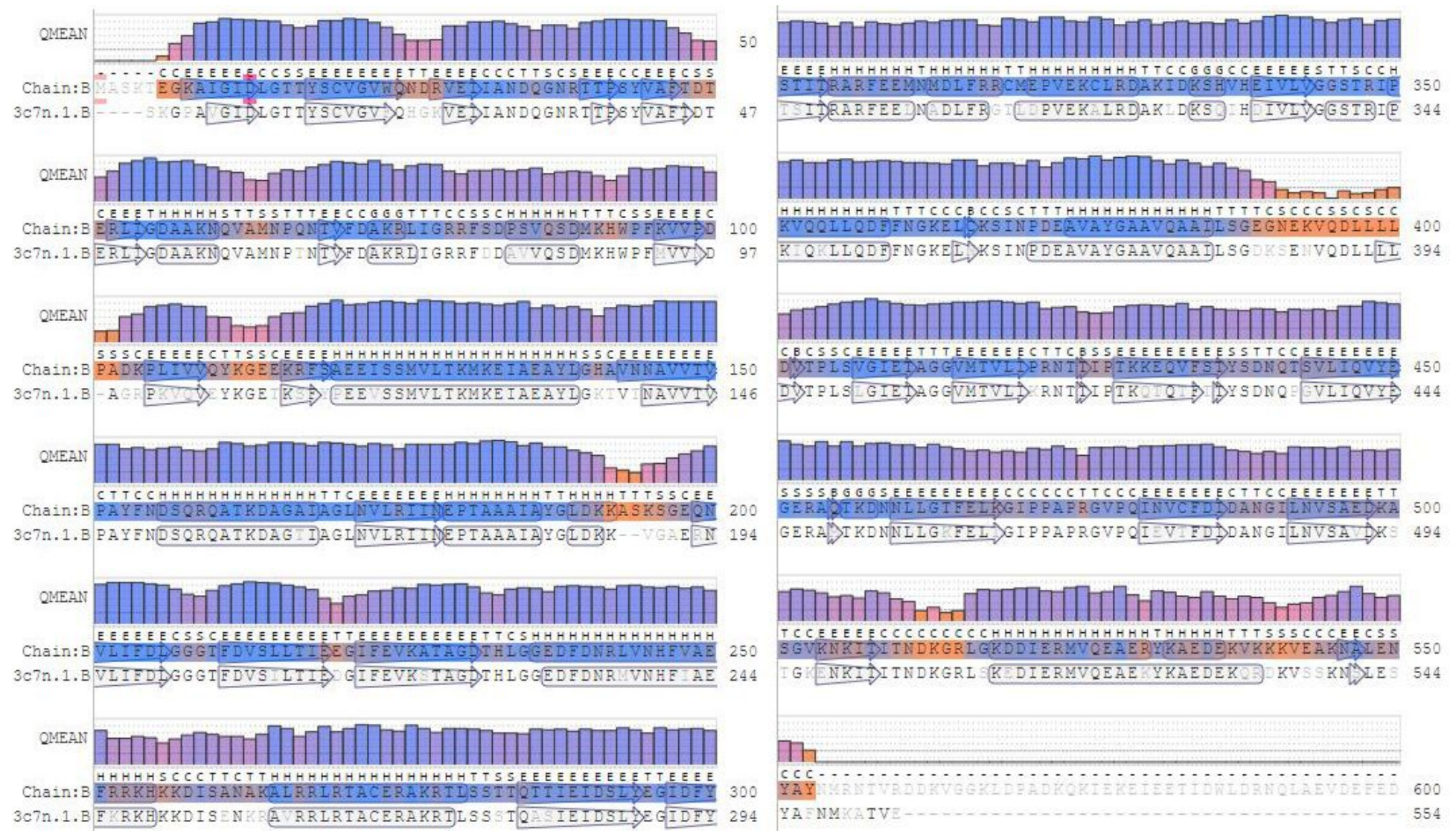

\section{Figure 6}

Aligning of B9N9W6 with template 3c7n.1.B amino acid sequences and secondary structure. The residues found in all protein polypeptide chains of the model are displayed in an interactive sequence display. Each residue is displayed by its one letter code below a bar chart displaying the QMEAN local quality estimation value. The secondary structure of the protein is displayed above each residue code as a single letter. $B$ : residue in isolated $\beta$-bridge; $C$ : loop or irregular; $E$ : extended strand, participates in $\beta$ ladder; G: 3-helix; H: a-helix; T: hydrogen bonded turn; S: bend. 

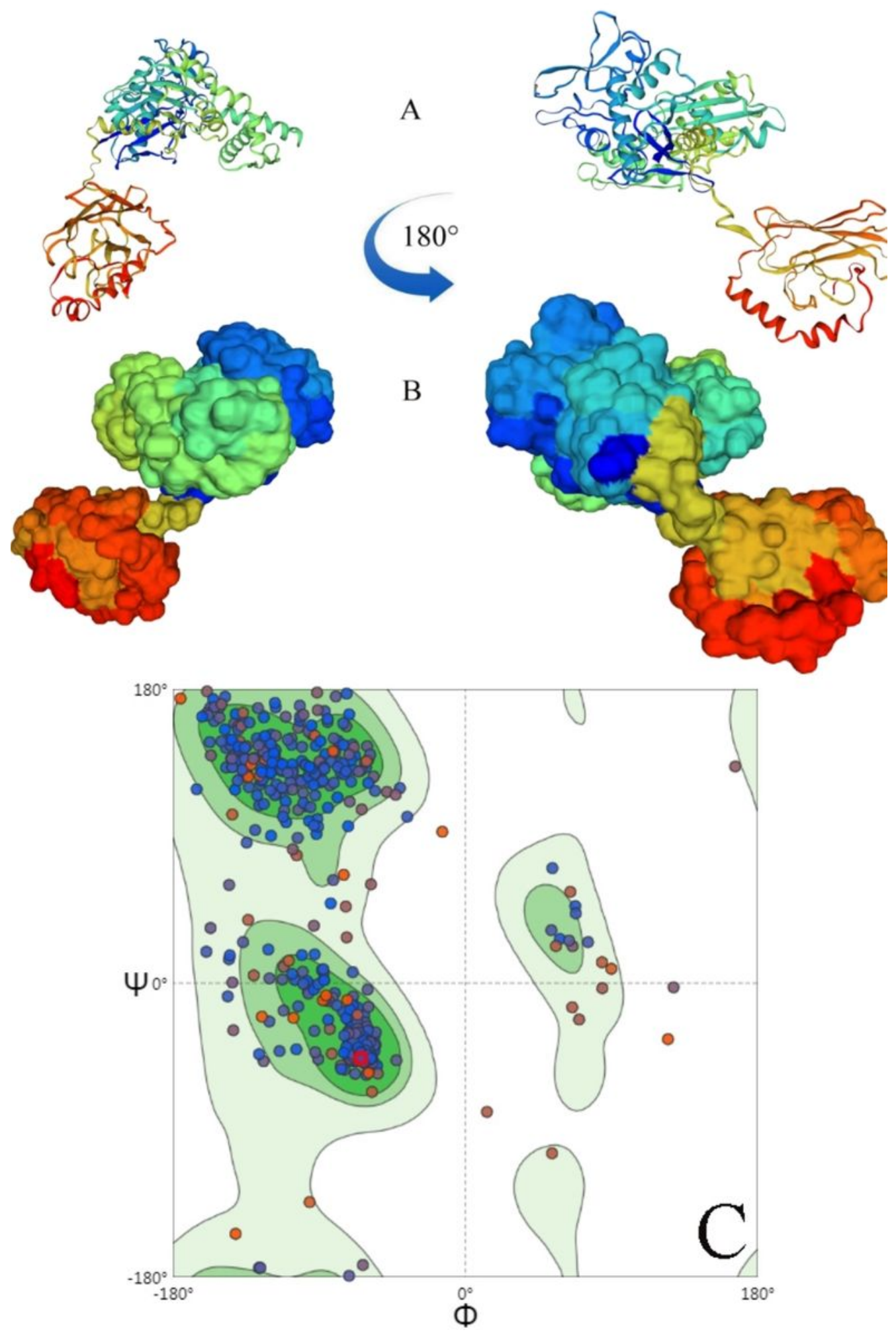

\section{Figure 7}

Molecular model diagram of B9N9W6 constructed by SWISS-Model. Template ID: 3c7n.1.B. QMEAN Value - 0.86 , GMQE Value 0.66 (The Qmean Value range is -4-0, and the closer it is to 0 , the better the matching degree between the target protein and the template. The confidence range of GMQE Value is 01, the higher the value, the better the quality of the model). A: Ribbon diagram of B9N9W6. B: Surface structure diagram of B9N9W6. C: Ramachandran Plots of B9N9W6. The number of residues in favored 
(90.11\%), in allowed regions (7.61\%) and in outlier regions (2.20\%), which demonstrates the high quality of the model construction.

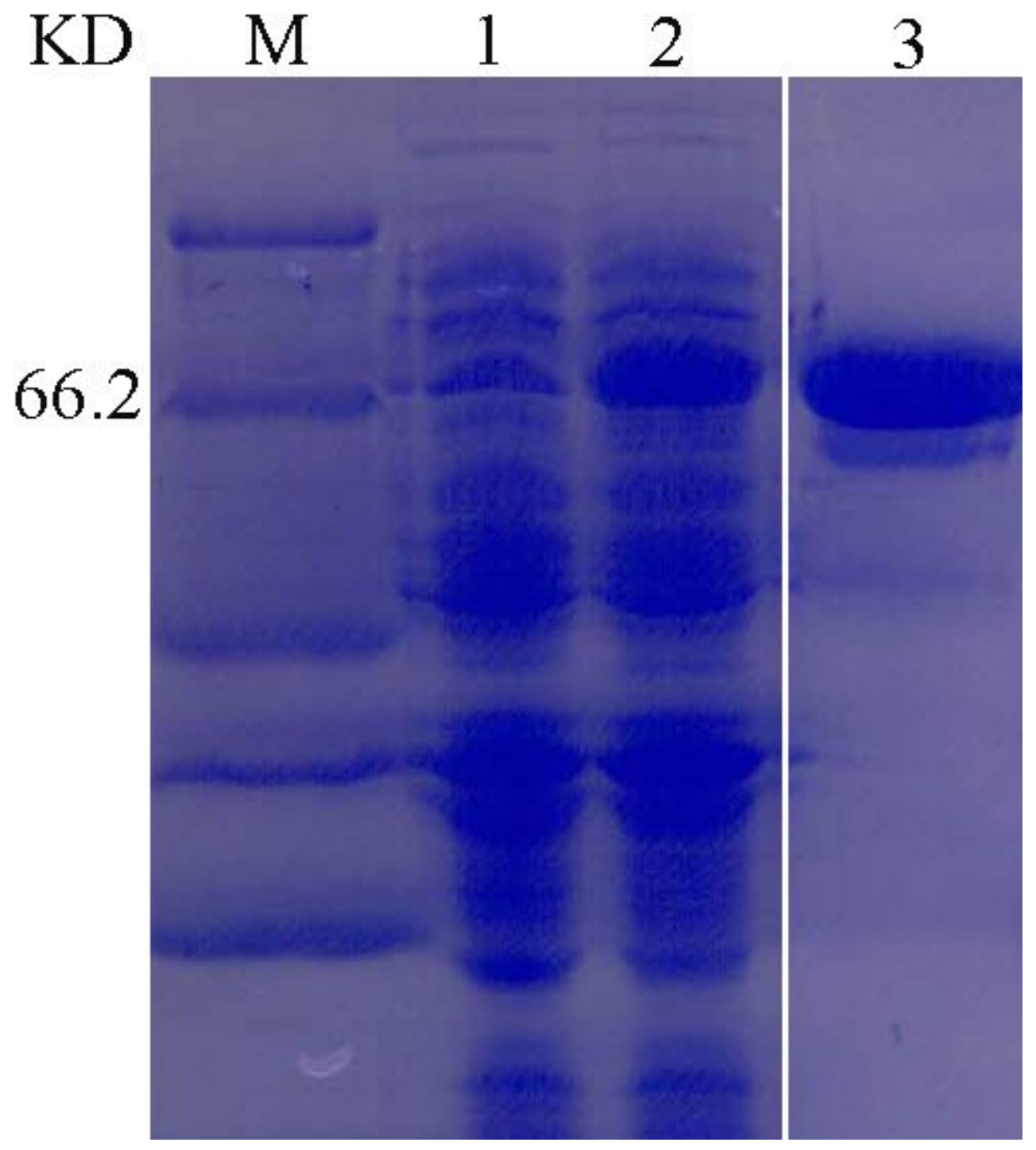

\section{Figure 8}

Prokaryotic expression and purification of B9N9W6. M: Protein Marker (C600525, Sangon Shanghai). 1: E. coli BL21- pET-28a (+). 2: E. coli BL21-pET-28a- B9N9W6. 3: purified product of B9N9W6. 

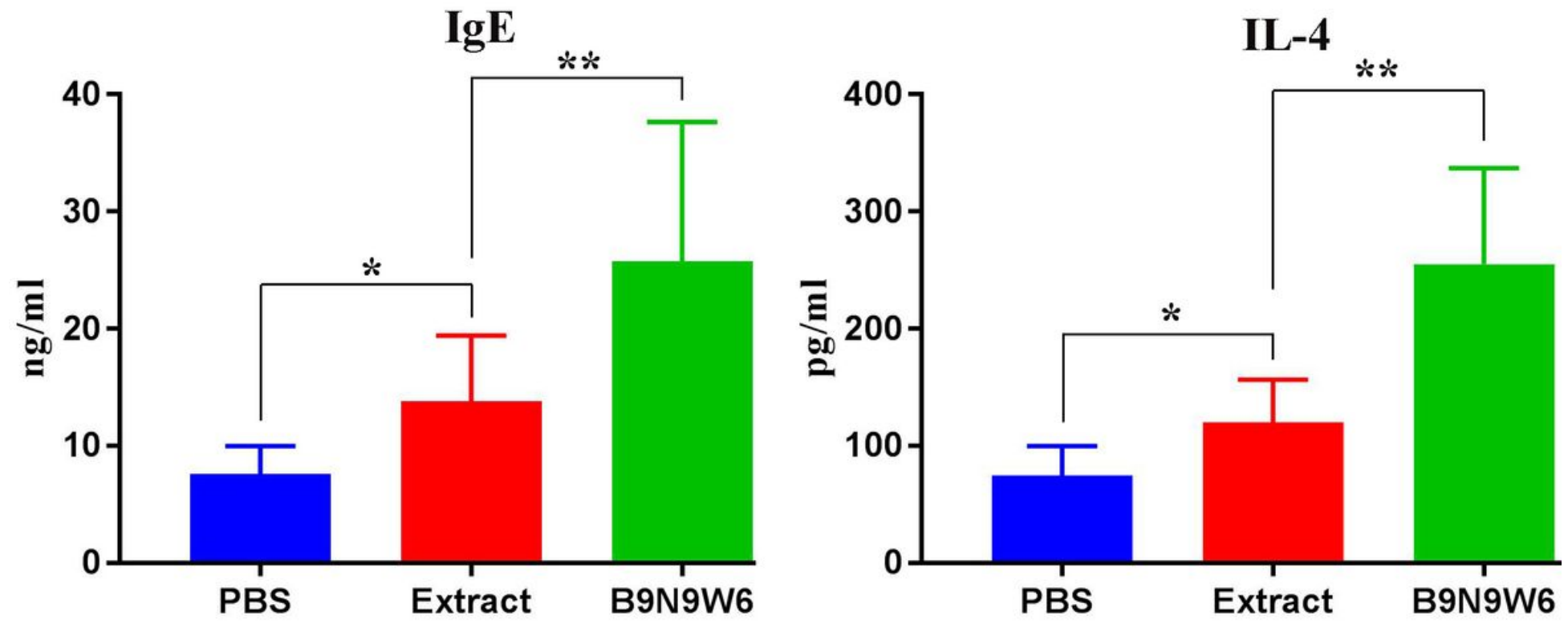

Figure 9

Effects of B9N9W6 on the expression of antibodies and cytokines. The vertical axis represents as the concentration of antibody or cytokine. Values are presented as the mean \pm standard deviation (SD). ${ }^{\mathrm{P}}<$ $0.05 ; * \star \mathrm{P}<0.01$. 

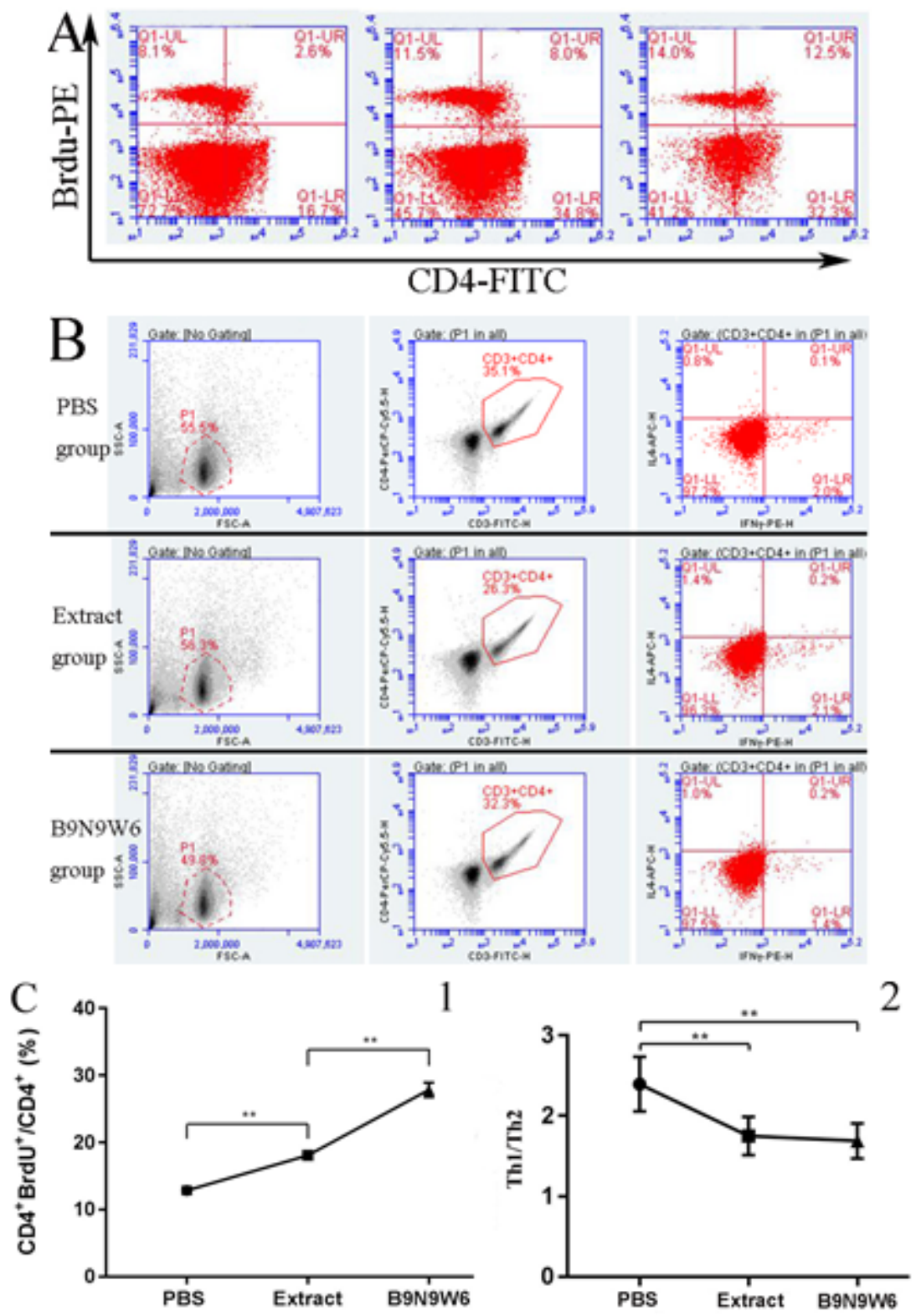

Figure 10

Proliferation of CD4+ T cells (A) and polarization of Th2(B) both treated with B9N9W6. C1: Proportion of $\mathrm{CD} 4+\mathrm{BrdU}+\mathrm{T}$ cells in terms of total CD4+ $\mathrm{T}$ cells in each experimental group. C2: Ratio of Th1/Th2. Values are presented as the percentages. ${ }^{* *} \mathrm{P}<0.01$. 


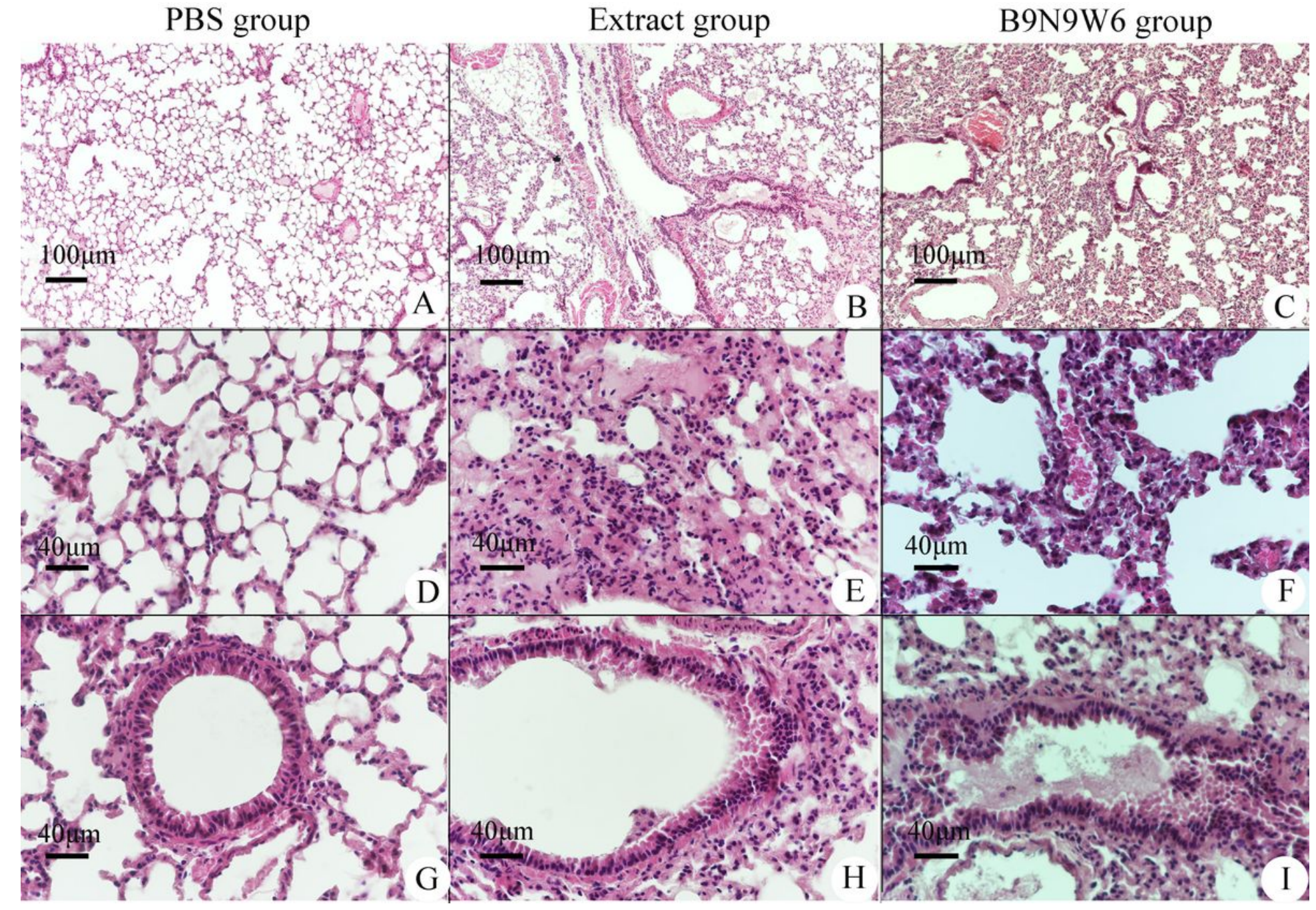

Figure 11

Inflammation and allergic pathological features in lung tissue of mouse model treated with B9N9W6. A-C: lung tissue (100x). D-F: alveolar (400x). G-I: terminal bronchus (400x).

\section{Supplementary Files}

This is a list of supplementary files associated with this preprint. Click to download.

- Annotationcombine.xlsx

- GOTermsLevel2Classify.xlsx

- GOenrichment.xlsx

- KEGGpathwayenrichment.xlsx

- MSidentifiedinformation.xlsx

- Proteindomainenrichment.xlsx

- SubcellularClassify.xlsx 
- map00010.png

- map00020.png

- map00030.png

- map00051.png

- map00052.png

- map00053.png

- map00061.png

- map00071.png

- map00190.png

- map00220.png

- map00250.png

- map00260.png

- map00261.png

- map00290.png

- map00300.png

- map00450.png

- map00480.png

- map00520.png

- map00620.png

- map00630.png

- map00650.png

- map00660.png

- map00710.png

- map00970.png

- map01200.png

- map01210.png

- map01212.png

- map01230.png

- map03010.png

- map03050.png

- map04141.png

- map04145.png 